\title{
Gas Exchanges and Biological Nitrogen Fixation in Soybean under Water Restriction
}

\author{
Paula Cerezini' ${ }^{1}$ Antonio Eduardo Pípolo², Mariangela Hungria², Marco Antonio Nogueira² \\ ${ }^{1}$ Department of Agronomy, Universidade Estadual de Londrina, Londrina, Brazil \\ ${ }^{2}$ Embrapa Soybean, Londrina, Brazil \\ Email: marco.nogueira@embrapa.br
}

Received 28 October 2014; revised 21 November 2014; accepted 19 December 2014

Copyright (C) 2014 by authors and Scientific Research Publishing Inc.

This work is licensed under the Creative Commons Attribution International License (CC BY). http://creativecommons.org/licenses/by/4.0/

(c) (i) Open Access

\begin{abstract}
Biological nitrogen fixation (BNF) in soybean is vulnerable to drought; however, there are genotypic variations among soybean cultivars regarding the ability to keep BNF under moderate water restriction. The aim of this study was to evaluate parameters related to gas exchanges and regulation of BNF in soybean genotypes BNF drought-tolerant (R01-581F and R01-416F), or droughtsusceptible (CD 215 and BRS 317), submitted to adequate water supply or restriction between 45 and 55 days after emergence. We searched for traits associated with tolerance/susceptibility to drought, which might be useful in the selection of drought-tolerant soybean genotypes. Plant biomass was not affected under water restriction, but the number and dry weight of nodules reduced by $33 \%$ and $12 \%$, respectively, in the average of genotypes. Drought-tolerant genotypes were more effective in maintaining gas exchanges under water restriction. Under water restriction, all genotypes increased the concentration of ureides in nodules, but only the susceptible genotypes showed that in leaves. The maintenance of gas exchanges and $\mathrm{N}$ metabolism regulation under water restriction in genotype R01-581F suggests that these parameters may be used to characterize soybean genotypes that can be sources of drought tolerance in genetic breeding programs.
\end{abstract}

\section{Keywords}

Bradyrhizobium, Drought, Glycine max, Photosynthesis, Ureides

\section{Introduction}

Soybean (Glycine max L. Merrill) is one of the most important agricultural crops with high economic importance worldwide, and Brazil stands as the second global producer. In 2013/2014, the Brazilian yield was 86.05 million tons, in a cropped area of 30.6 million ha, with an increase of 5.5\% in yield and 9.4\% in area, compared 
to 2012/2013 season [1]. Soybean has high nitrogen (N) demand for growth, which can be mostly provided via biological nitrogen fixation (BNF). This process is essential for the economic viability of soybean crop in Brazil and is based on the symbiosis with bacteria belonging to the genus Bradyrhizobium, providing nearly all $\mathrm{N}$ required by plant, making this crop independent of $\mathrm{N}$-fertilizers, with economic and environmental benefits [2] [3].

Several factors may impair soybean yield, such as drought events, which may intensify in a near future as consequence of climate changes [4]. Water restriction affects physiological and nutritional processes in plants, impairing the efficiency of BNF [5]. The factors involved in reduction/inhibition of BNF under drought are not well understood, but evidences point out that accumulation of $\mathrm{N}$ compounds like ureides in leaves and nodules due to restriction in transport leads to a negative feedback to BNF [6] [7]. However, some studies suggest that there are genotypic variations among soybean genotypes in relation to the ability to keep not only the symbiotic process, but also physiological processes, as photosynthesis and transpiration rate under drought [5]. The genotypes R01-581F and R01-416F were originated from crossings between the cultivars "Jackson" (identified as $\mathrm{N}_{2}$-fixation drought tolerant-NFDT, i.e. maintain BNF under drought) and KS4895 (high potential for yield). The offspring were selected under water restriction to maintain high productivity, higher amounts of $\mathrm{N}$ accumulated in shoots, and high activity of the enzyme nitrogenase [5] [8]. However, further studies about plant physiology and $\mathrm{N}$-metabolism in genotypes with potential for higher resistance to drought are needed, in order to confirm the NFDT phenotype.

The aim of this study was to evaluate attributes related to gas exchanges and regulation of BNF of soybean genotypes under water restriction, to characterize phenotypic differences associated with tolerance/susceptibility to drought, which may be useful in the selection for breeding programs of soybean cultivars for drought tolerance.

\section{Material and Methods}

The trial was conducted between Nov 2011 and Jan 2012, under greenhouse conditions at Embrapa Soybean, Londrina, PR, Brazil. The experimental design was entirely randomized, in a $4 \times 2$ factorial arrangement, with four replicates. The NFDT soybean genotypes, R01-581F and R01-416F [8], and the drought-susceptible genotypes, CD 215 and BRS 317, were kept under adequate water supply or subjected to water restriction between 45 and 55 days after emergence (DAE).

A topsoil sample, obtained at $0-20 \mathrm{~cm}$ from an agricultural soil used for soybean cropping, classified as Typic Acrudox (USDA soil taxonomy), was used as substrate. The result of chemical analysis revealed: $\mathrm{pH}\left(\mathrm{CaCl}_{2}\right)=$ 4.7; organic matter $=33 \mathrm{~g} \cdot \mathrm{kg}^{-1} ; \mathrm{P}($ Mehlich I $)=2.14 \mathrm{mg} \cdot \mathrm{dm}^{-3} ; \mathrm{K}=0.31 \mathrm{cmol}_{\mathrm{c}} \cdot \mathrm{dm}^{-3}, \mathrm{Ca}=4.02 \mathrm{cmol}_{\mathrm{c}} \cdot \mathrm{dm}^{-3}, \mathrm{Mg}=$ $0.64 \mathrm{cmol}_{\mathrm{c}} \cdot \mathrm{dm}^{-3}, \mathrm{H}+\mathrm{Al}=5.6 \mathrm{cmol}_{\mathrm{c}} \cdot \mathrm{dm}^{-3}, \mathrm{CEC}=10.5 \mathrm{cmol}_{\mathrm{c}} \cdot \mathrm{dm}^{-3}, \mathrm{SB}=4.97, \mathrm{~V}=47 \%, \mathrm{Al}=0 \mathrm{cmol}_{\mathrm{c}} \cdot \mathrm{dm}^{-3}$; particle size fraction: sand $=732 \mathrm{~g} \cdot \mathrm{kg}^{-1}$, silt $=30 \mathrm{~g} \cdot \mathrm{kg}^{-1}$, clay $=238 \mathrm{~g} \cdot \mathrm{kg}^{-1}$. Based on the chemical analysis, the substrate received $2.2 \mathrm{~g}$ of $\mathrm{CaCO}_{3}$ per $\mathrm{kg}$ to raise the $\mathrm{pH}$ to 6.5 . Three-kg aliquots of the substrate were placed into ceramic pots, provided with water to reach $90 \%$ of field capacity and incubated for 30 days. Before sowing, each pot received $40 \mathrm{mg}$ of $\mathrm{P}, 235 \mathrm{mg}$ of $\mathrm{K}$ (both as $\mathrm{K}_{2} \mathrm{HPO}_{4}$ ), $170 \mathrm{mg}$ of $\mathrm{Mg}, 230 \mathrm{mg}$ of S (both as $\mathrm{MgSO}_{4} \cdot 7 \mathrm{H}_{2} \mathrm{O}$ ), and $50 \mathrm{~mL}$ of a micronutrient solution containing $0.8 \mathrm{mg}$ of $\mathrm{CoSO}_{4}, 3.2 \mathrm{mg}$ of $\mathrm{Na}_{2} \mathrm{MO}_{4}$ and $0.3 \mathrm{~g}$ of $\mathrm{H}_{3} \mathrm{BO}_{3}$ in $5 \mathrm{~L}$ of water. None chemical $\mathrm{N}$ was added, which was provided only via BNF, based on inoculation of the seeds with a mixture of Bradyrhizobium japonicum (SEMIA 5079) and B. diazoefficiens (SEMIA 5080), as recommended in Brazil, maintaining one plant per pot. During the trial, daily temperatures and relative humidities were measured with a thermohygrometer. The average day/night temperatures ranged between $37.2^{\circ} \mathrm{C}$ and $21.9^{\circ} \mathrm{C}$, respectively, and the average day/night relative humidities ranged from $37.7 \%$ to $82.5 \%$, respectively.

The water holding capacity (WHC) of soil was determined in a tension table and Richards's extractor device [9], which allowed the construction of a curve of water retention and determination of water potential $\left(\psi_{\mathrm{w}}\right)$. During the first $45 \mathrm{DAE}$, plants received water daily to keep the $\psi_{\mathrm{w}}$ of soil at $-13 \mathrm{MPa}\left(0.300 \mathrm{~L} \cdot \mathrm{L}^{-1}\right.$ of soil $)$, which represent a fraction of available water (FAW) of 0.9 (wet condition). At the full flowering (R2) stage, half of the plants were subjected to moderate drougth between 45 and $55 \mathrm{DAE}$ by keeping the $\psi_{\mathrm{w}}$ of soil at $-200 \mathrm{MPa}\left(0.090 \mathrm{~L} \cdot \mathrm{L}^{-1}\right.$ of soil), corresponding to a FAW of 0.27 (dry condition), to mimetize a moderate water restriction. The remaining pots continued to receive adequate water supply to a FAW of 0.9 . Soil moisture was monitored daily by weighing the pots on an electronic scale, with correction of moisture according to the water regime. We considered the plant biomass in extra pots at wet condition to eliminate the effect of the plant weight on the calculation of water to be supplied within the period under drougth stress. 
During the period of water restriction, SPAD units were measured with a portable meter, model SPAD-502 (Konica Minolta Sensing Inc., Osaka, Japan), and converted to chlorophyll content $\left(\mu \mathrm{g} \cdot \mathrm{cm}^{-2}\right)$ as described KASCHUK et al. [10]. The air temperature and the estimated global radiation (Qg-i) within the greenhouse were also recorded. Stomatal conductance ( $\mathrm{mol} \mathrm{H}_{2} \mathrm{O} \mathrm{m} \mathrm{m}^{-2} \cdot \mathrm{s}^{-1}$ ), net photosynthetic rate $\left(\mu \mathrm{mol} \mathrm{CO}_{2} \mathrm{~m}^{-2} \cdot \mathrm{s}^{-1}\right.$ ), transpiration rate ( $\mathrm{mmol} \mathrm{H} \mathrm{H}_{2} \mathrm{O} \mathrm{m}^{-2} \cdot \mathrm{s}^{-1}$ ), intercellular $\mathrm{CO}_{2}$ concentration $\left(\mu \mathrm{mol} \mathrm{CO}_{2} \mathrm{~mol}^{-1}\right)$ and temperature of leaves $\left({ }^{\circ} \mathrm{C}\right)$ were recorded in the third recently expanded trifoliolate, at the $55^{\text {th }} \mathrm{DAE}$, between 8:00 and 10:00 a.m., with a portable gas-exchange meter, model LI-6400 (Li-Cor, Biosciences Inc., Nebraska, USA).

After measurements, plants were harvested; shoots and roots were dried at $60^{\circ} \mathrm{C}$ for $48 \mathrm{~h}$ and shoot and root dry weights (SDW and RDW, respectively), number of nodules (NN) and nodule dry weights (NDW) were obtained. For $\mathrm{N}$ concentrations, leaves were grinded, digested in sulfuric extract and the $\mathrm{N}$ determined by the green salicylate colorimetric method [11]. Dry leaves, petioles and nodules were grinded separately for determination of ureides according to VOGELS and VAN DER DRIFT [12].

The dataset was submitted to ANOVA with application of $\mathrm{F}$ test at $\mathrm{p} \leq 0.05$. Once the effects of treatments or interactions between the factors were detected, means were compared by Tukey's test at $\mathrm{p} \leq 0.05$.

\section{Results}

The net photosynthetic rate and temperature of leaves had only isolated effect of factors (Figure 1). The genotypes R01-581F showed higher net photosynthetic rate in relation to CD 215 and BRS 317, regardless the water condition (Figure 1(a)). On average, water restriction reduced the net photosynthetic activity by $28 \%$ in relation to plants well watered. Water restriction reduced the transpiration rate in all genotypes, especially the susceptible $(-56 \%)$ compared to the tolerant genotypes $(-26 \%)$ (Figure 1(b)). The same trend was observed for intercellular $\mathrm{CO}_{2}$, which reduced by $25 \%$ in the susceptible genotypes and only by $10 \%$ in the tolerant ones (Figure $1(\mathrm{c})$ ), without significant reduction in R01-581F, considering the interaction between factors. Similarly, water restriction reduced the stomatal conductance by $76 \%$ in the susceptible and only by $48 \%$ in the tolerant genotypes (Figure 1(d)). Water condition also affected the temperature of leaves, almost $1^{\circ} \mathrm{C}$ higher under water restriction, in the average of genotypes, considering the isolate effect (Figure 1(e)). However, water restriction did not affect the chlorophyll content, which tended to increase between 45 - 55 DAE (Figure 1(f)). Data on temperature and solar radiation inside the greenhouse during the induction of drought are shown in Figure 1(f), inner graph.

No interactions between genotypes and water condition were observed for plant biomass, which varied only with genotypes, but not with water conditions (Figure 2(a) and Figure 2(b)). Irrespectively of water condition, CD 215 produced more SDW than R01-581F (Figure 2(a)), whereas BRS 317 had greater RDW than R01-581F and R01-416F (Figure 2(b)). Despite no effect on plant biomass, water restriction decreased NDW and NN by $33 \%$ and 12\%, respectively, in the average of genotypes (Figure 2(c) and Figure 2(d)). The genotype R01-581F had the highest NN compared to CD 215, irrespectively of water condition.

$\mathrm{N}$ concentrations in leaves and ureide contents in leaves, petioles and nodules showed interation between factors (Figure 3). Higher $\mathrm{N}$ concentrations in leaves were observed in the tolerant R01-581F, in relation to the susceptible, in both water conditions (Figure 3(a)), whereas only R01-416F had decrease in N concentration under water restriction. Water restriction did not affect the ureide contents in leaves of NFDT genotypes, but increased them by $85 \%$ in the susceptible ones (Figure 3(b)). Only R01-581F did not increase significantly the ureide contents in petioles under water restriction (Figure 3(c)), whereas the other genotypes increased by $100 \%$ or more in the same condition. The ureide contents in nodules increased more than $100 \%$ for all genotypes exposed to water restriction (Figure 3(d)). Under full water sypply, the genotypes did not show differences in ureide contents in nodules; under water restriction, BRS 317 had significant reduction compared to R01-416F, R01-581F and CD 215, which did not differ each other.

\section{Discussion}

The vulnerability of BNF in soybean under water restriction is known and has been studied for decades [5] [6]. However, the mechanisms related to tolerance/susceptibility of BNF to drought are still not well understood. In our study, the hypothesis of regulation of BNF by N metabolism can be supported, since water restriction altered the concentrations of ureides in several plant parts, especially nodules, where they may act negatively on the BNF in a feedback effect. A similar mechanism has been reported for common bean (Phaseolus vulgaris L.) under thermal stress [13]. 

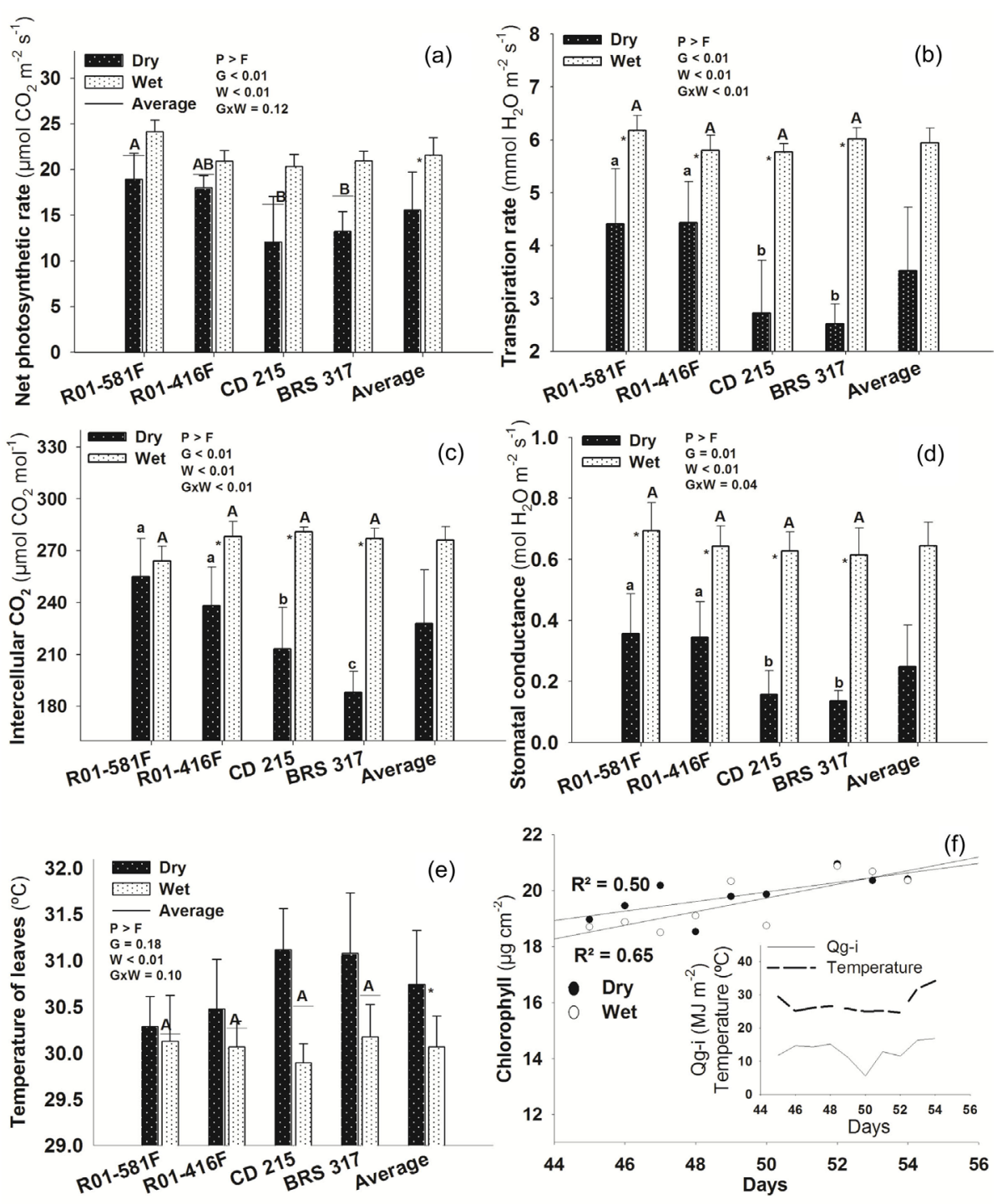

Figure 1. Net photosynthetic (a) and transpiration (b) rates, intercellular $\mathrm{CO}_{2}$ concentration (c), stomatal conductance (d), temperature of leaves (e) in the $55^{\text {th }}$ day after emergence-DAE-and chlorophyll content (f) in soybean genotypes that show $\mathrm{N}_{2}$ fixation drought-tolerance (R01-581F and R01-416F) or drought-susceptibility (CD 215 and BRS 317), kept under wet or dry conditions between 45 and 55 DAE. Means with the same letters do not differ one another (Tukey, p $<0.05$ ); capital letters on columns compare genotypes at wet condition; small letters compare at dry condition; capital letters on horizontal bars compare genotypes in the average of water condition in the non-significant interaction; *Significant effect of water condition in each genotype $(n=4$, Figures $b$, c and $d)$ or in the average of genotypes $(n=16$, Figures a and e) in the non-significant interaction. $\mathrm{G}=$ Genotypes; $\mathrm{W}=$ Water condition. Inner graph in Figure (f) represent solar radiation inside the greenhouse (Qg-i) and temperature between 45 - 55 DAE. Vertical bars represent the standard deviation.

The nodule activity is sensitive to water balance in plants [3], because the xylem flow is essential for exportation of $\mathrm{N}$ compounds, as ureides, from nodules to shoots, and thus preventing a feedback inhibition on BNF. The phloem flow, on the other hand, is responsible for providing water and photosynthates to nodules, sustaining the BNF, a highly energy-demanding process [3]. The reduction of transpiration rates in all genotypes under water limitation hampered the transport of ureides, since the transpiration produces the necessary mass flow for exportation of water and nutrients via xylem. Thus, decrease in the transpiration rates affected the translocation of ureides, resulting in substantial accumulation in nodules and petioles in the majority of genotypes. LADRERA et al. [7] also observed accumulation of ureides in soybean nodules under water restriction, resulting in inhibition of the nitrogenase, and thus hindering the $\mathrm{N}$ supply to the crop. However, only R01-416F decreased $\mathrm{N}$ 

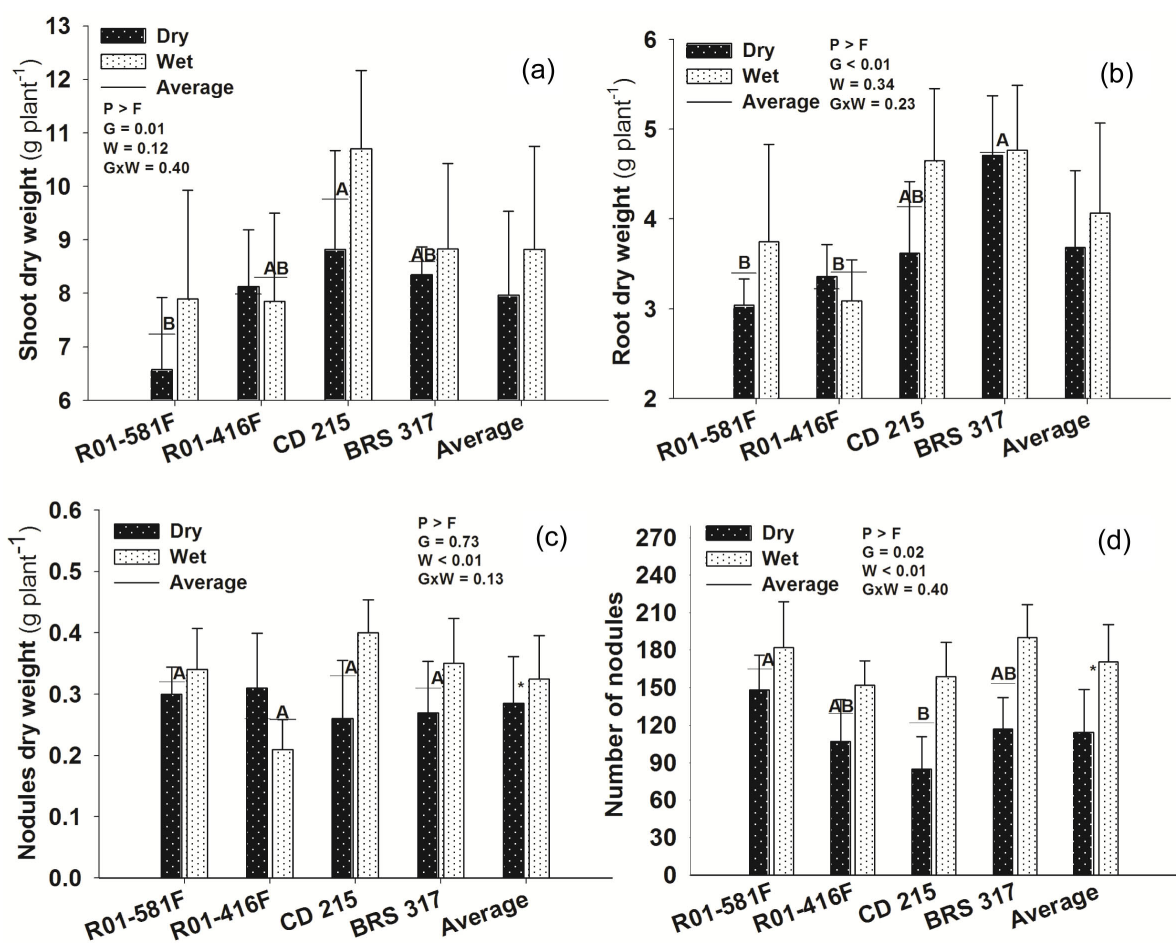

Figure 2. Shoot (a) and root dry weights (b), nodule dry weights (c) and number of nodules (d) in the $55^{\text {th }}$ day after emergence-DAE-in soybean genotypes showing $\mathrm{N}_{2}$ fixation drought-tolerance (R01-581F and R01-416F) or droughtsusceptibility (CD 215 and BRS 317), kept under wet or dry conditions between 45 and 55 DAE. Means followed by the same letters on horizontal bars do not differ one another (Tukey, $\mathrm{p}<0.05$ ) and compare genotypes in the average of water condition in the non-significant interaction; *Significant effect of water condition in the average of genotypes $(n=16)$ in the non-significant interaction. $\mathrm{G}=$ Genotypes; $\mathrm{W}=$ Water condition. Vertical bars represent the standard deviation.

concentrations in leaves under water restriction, suggesting that time and/or severity of stress was not enough to cause the same effects in the other genotypes. Nevertheless, as ureide contents as NN and NDW were altered, demonstrating that changes in the BNF under water stress are very fast, often impairing the BNF before the leaf $\mathrm{N}$ concentration, gas exchanges [3], or plant biomass.

The genotype R01-581F stood out for not showing changes in ureide concentrations in petioles under water restriction. Despite reduction in transpiration rate, this decrease was less expressive than in the susceptible genotypes. Moreover, R01-581F showed more stable physiological activities like net photosynthesis, intercellular $\mathrm{CO}_{2}$, and temperature of leaves under water restriction. The maintenance of these processes indicates that R01-581F has not only protective features to keep BNF under drought, but also the processes related to gas exchanges. This can help to keep a better performance of BNF under drought, since the plant remains able to feed the bacteroids via photo assimilates and transport of $\mathrm{N}$ compounds via transpiratory flow, and thus relief the inhibitory feedback effect of ureides on nitrogenase activity.

Although stomatal conductance had been reduced in all genotypes, it was more drastic in the drought-susceptible genotypes, resulting in higher leaf temperatures and lower gas exchanges when compared to the tolerant genotypes. Moreover, R01-581F and R01-416F did not show changes in the ureide contents in leaves under drougth, whereas the susceptible genotypes had increase. SILVENTE et al. [14] found the same trend, wherein only the soybean drought-susceptible genotype showed accumulation of ureides in leaves, under water restriction. The characteristic of NFDT of the genotype Jackson, among other factors, seems to be associated with its ability to minimize the accumulation of ureides in leaves [5]. This characteristic was observed mainly for R01-581F, whose Jackson is parental, suggesting that they provide better maintenance of $\mathrm{N}$ metabolism, being able to sustain the BNF longer under conditions of moderate drought stress. R01-416F, however, showed accumulation of ureides in petioles and decrease of $\mathrm{N}$ concentration in leaves under drought.

Changing the allocation patterns of $\mathrm{C}$ is a further adaptive characteristic of plants to relief the damages caused by drought, with reduction of shoots and elongation of root system. The reduced potential for water loss and, at 

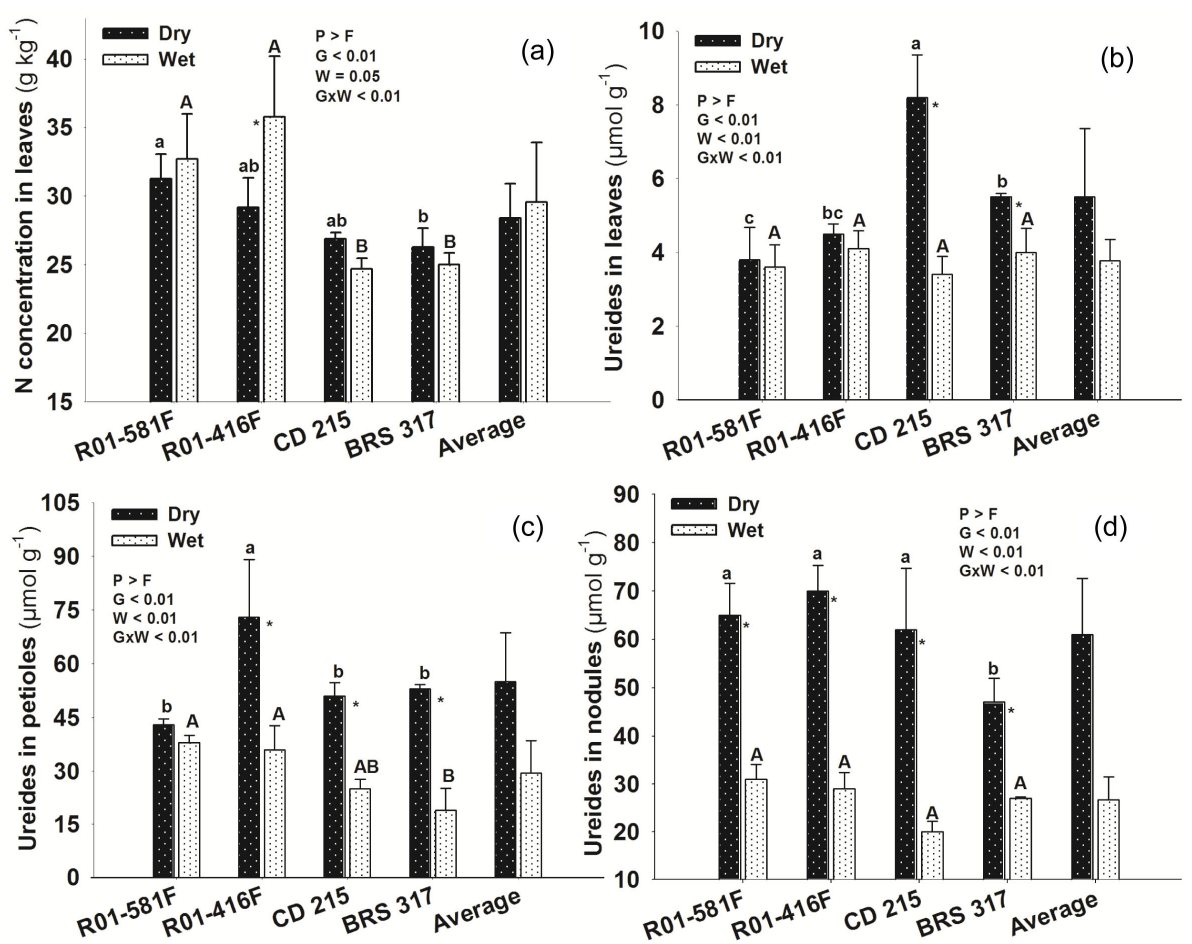

Figure 3. $\mathrm{N}$ concentration in leaves (a), ureide contents in leaves (b), petioles (c) and nodules (d) in the $55^{\text {th }}$ day after emergence-DAE - in soybean genotypes showing $\mathrm{N}_{2}$ fixation drought-tolerance (R01-581F and R01-416F) or droughtsusceptibility (CD 215 and BRS 317), kept under wet or dry conditions between 45 and 55 DAE. Means with the same letters do not differ one another (Tukey, $\mathrm{p}<0.05$ ); capital letters on columns compare genotypes at wet condition; small letters compare at dry condition; * Significant effect of water condition in each genotype $(n=4)$. $G=$ Genotypes; W = Water condition. Vertical bars represent the standard deviation.

the same time, the prolongation of the root system allows exploitation of water in deeper soil layers [15]. However, we did not observe significant changes in plant biomass (shoots and roots) in this study. Again, the time and/or severity of stress could not have been enough to cause changes in SDW and RDW, but changes in NN and NDW were noticeable, emphasizing the sensibility of the symbiosis to drought.

\section{Conclusions}

The genotype R01-581F confirmed its superiority facing water restriction, due to its ability to slow down the effects of drought in the plant as a whole, including the maintenance of gas exchanges, and translocation and metabolism of ureides, mainly in leaves and petioles.

The parameters cited above were showed to be promising tools for characterization of soybean genotypes that can be sources of drought tolerance in genetic breeding programs.

\section{Acknowledgements}

The authors acknowledge the laboratory of Agro meteorology at Embrapa Soybean for the data on solar radiation. P. Cerezini acknowledges a fellowship from CAPES; M.A. Nogueira and M. Hungria are CNPq research fellows. Financial support by Embrapa, research project \#02.09.01.023.00.00 and CNPq-Repensa \#562008/ 2010-1. This paper was approved for publication by the Editorial Board of Embrapa Soybean as manuscript number 07/2014.

\section{References}

[1] CONAB (COMPANHIA NACIONAL De ABASTECIMENTO) (2014) Acompanhamento da safra brasileira: Grãos, décimo levantamento, CONAB, safra 2013/2014. http://www.conab.gov.br 
[2] Hungria, M., Campo, R.J. and Mendes, I.C. (2007) A importância do processo de fixação biológica do nitrogênio para a cultura da soja: Componente essencial para a competitividade do produto brasileiro. Embrapa Soja. Documentos, 283, Embrapa Soja, Londrina. http://www.infoteca.cnptia.embrapa.br/handle/doc/468512

[3] Sinclair, T.R. and Vadez, V. (2012) The Future of Grain Legumes in Cropping Systems. Crop Pasture Science, 63, 501-512. http://dx.doi.org/10.1071/CP12128

[4] IPCC (Intergovernmental Panel on Climate Change) (2007) Climate Change: The Physical Science Basis. Contribution of Working Group I to the Fourth Assessment Report of the Intergovernmental Panel on Climate Change. IPCC, Paris. http://www.ipcc.ch

[5] Sinclair, T.R., Purcell, L.C., King, A., Sneller, C.H., Chen, P. and Vadez, V. (2007) Drought Tolerance and Yield Increase of Soybean Resulting from Improved Symbiotic $\mathrm{N}_{2}$ Fixation. Field Crops Research, 101, 68-71. http://dx.doi.org/10.1016/j.fcr.2006.09.010

[6] Serraj, R., Sinclair, T.R. and Purcell, L.C. (1999) Symbiotic $\mathrm{N}_{2}$ Fixation Response to Drought. Journal of Experimental Botany, 50, 143-155.

[7] Ladreira, R., Marino, D., Larrainzar, E., González, E.M. and Arrese-Igor, C. (2007) Reduced Carbon Availability to Bacteroids and Elevated Ureides in Nodules, but Not in Shoots, Are Involved in the Nitrogen Fixation Response to Early Drought in Soybean. Plant Physiology, 145, 539-546. http://dx.doi.org/10.1104/pp.107.102491

[8] Chen, P., Sneller, C.H., Purcell, L.C., Sinclair, T.R., King, C.A. and Ishibashi, T. (2007) Registration of Soybean Germplasm Lines R01-416F and R01-581F for Improved Yield and Nitrogen Fixation under Drought Stress. Journal of Plant Registrations, 1, 166-167. http://dx.doi.org/10.3198/jpr2007.01.0046crg

[9] EMBRAPA (Empresa Brasileira de Pesquisa Agropecuária) (1997) Manual de métodos de análise de solo. EMBRAPA-CNPS. Documentos 1, Centro Nacional de Pesquisa de Solos, EMBRAPA, Rio de Janeiro.

[10] Kaschuk, G., Hungria, M., Leffelaar P.A., Giller, K.E. and Kuyper, T.W. (2010) Differences in Photosynthetic Behaviour and Leaf Senescence of Soybean [Glycine max (L.) Merrill] Dependent on $\mathrm{N}_{2}$ Fixation or Nitrate Supply. Plant Biology, 12, 60-69. http://dx.doi.org/10.1111/j.1438-8677.2009.00211.x

[11] Searle, P.L. (1984) The Berthelot or Indophenol Reaction and Its Use in the Analytical Chemistry of Nitrogen. Analyst, 109, 549-568. http://dx.doi.org/10.1039/an9840900549

[12] Vogels, G.D. and van der Drift, C. (1970) Differential Analysis of Glyoxylate Derivatives. Analytical Biochemistry, 33, 143-157. http://dx.doi.org/10.1016/0003-2697(70)90448-3

[13] Hungria, M. and Kaschuk, G. (2014) Regulation of $\mathrm{N}_{2}$ Fixation and $\mathrm{NO}_{3}{ }^{-} / \mathrm{NH}_{4}{ }^{+}$Assimilation in Nodulated and N-Fertilized Phaseolus vulgaris L. Exposed to High Temperature Stress. Environmental and Experimental Botany, 98, 32-39. http://dx.doi.org/10.1016/j.envexpbot.2013.10.010

[14] Silvente, S., Sobolev, A.P. and Lara, M. (2012) Metabolite Adjustments in Drought Tolerant and Sensitive Soybean Genotypes in Response to Water Stress. PLoS ONE, 7, e38554.

[15] Lopes, M.S., Araus, J.L., van Heerden, P.D.R. and Foyer, C.H. (2011) Enhancing Drought Tolerance in C4 Crops. Journal of Experimental Botany, 62, 3135-3153. 
Scientific Research Publishing (SCIRP) is one of the largest Open Access journal publishers. It is currently publishing more than 200 open access, online, peer-reviewed journals covering a wide range of academic disciplines. SCIRP serves the worldwide academic communities and contributes to the progress and application of science with its publication.

Other selected journals from SCIRP are listed as below. Submit your manuscript to us via either submit@scirp.org or Online Submission Portal.
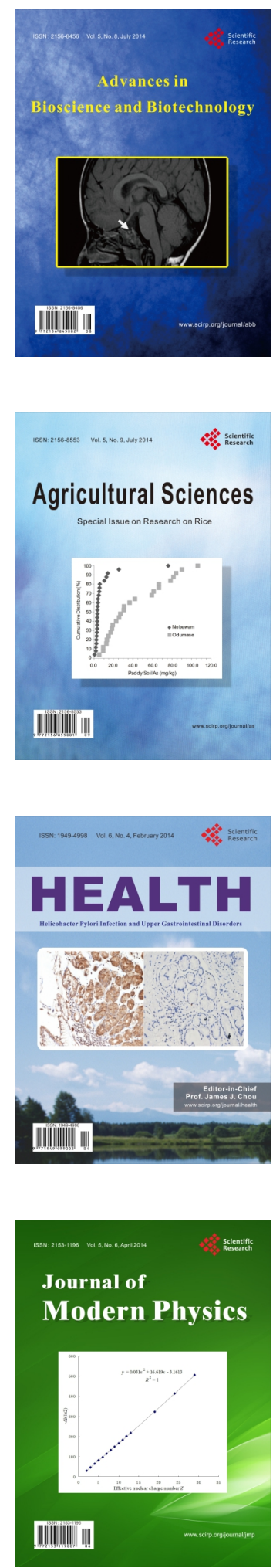
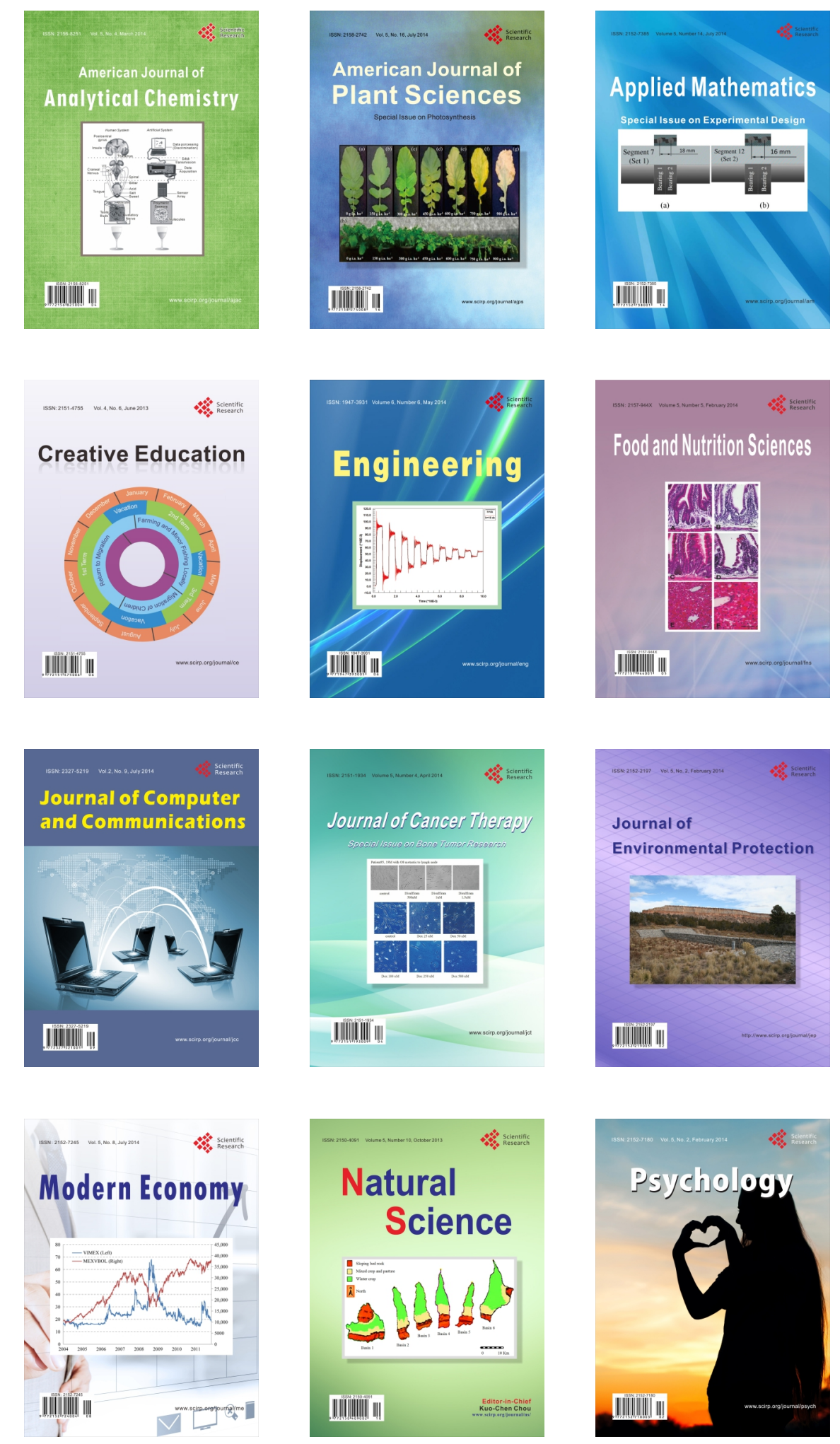